\title{
The Life of Józef Warszewicz (1812-1866): the Kraków Period
}

\author{
Piotr Köhler \\ Institute of Botany, \\ Jagiellonian University \\ Kopernika 27, \\ 31-501 Kraków, Poland \\ E-mail: piotr.kohler@uj.edu.pl
}

\begin{abstract}
Józef Warszewicz (1812-1866), one of the most prolific nineteenthcentury plant collectors and one of the top field experts on tropical American plants of his time, after spending several years on expeditions to Central and South America, was to be employed as Inspector (the main gardener) of the Botanical Garden of the Jagiellonian University in Kraków. His employment encountered resistance from the Ministry of Denominations and Education in Vienna. After a nearly four-year effort, Warszewicz took up his post in Kraków in 1854. He worked on the reorganisation of the Botanical Garden and supervised new projects there. His activities contributed to an expansion of the Botanical Garden's plant collections. Warszewicz also brought a herbarium and a collection of tropical animals to Kraków. During his life in Kraków, Warszewicz was widely honoured, and after his death, a monument was erected to him and one of Kraków's streets was named after him.
\end{abstract}

Keywords: botanical collections, Józef Warszewicz, Kraków Botanical Garden, orchids, zoological collections

Józef Warszewicz (Fig. 1) was one of the most unusual people connected with Polish science in the mid-nineteenth century. He was born in Vilna (then part of the Russian Empire, now the capital of Lithuania) in the famous year 1812, in which Vilna, as a result of the Napoleonic Wars, enjoyed six months of freedom from Russian rule. Nearly twenty years later Warszewicz took part in the November Uprising (1830-1831). Following the collapse of the insurrection, he, along with 15,000 insurgents, crossed the border into the Kingdom of Prussia in mid-July 1831. In Prussia he worked in botanical gardens, first in Insterburg (now Chernyakhovsk, Kaliningrad Oblast, Russia) in eastern Prussia, then in 
the royal gardens in Potsdam, and finally at FriedrichWilhelms-Universität in Schöneberg near Berlin. Thanks to the support of Alexander von Humboldt (1769-1859), he joined a group of Belgian settlers and travelled to Guatemala in 1845. After returning from this expedition he travelled to South America (Köhler \& Mirek, 2010/2011)1. Thanks to his intensive collecting of plants during these trips, Warszewicz has become one of the most famous South American plant collectors of the nineteenth century.

Józef Warszewicz’s Kraków period lasted thirteen years, beginning with his arrival

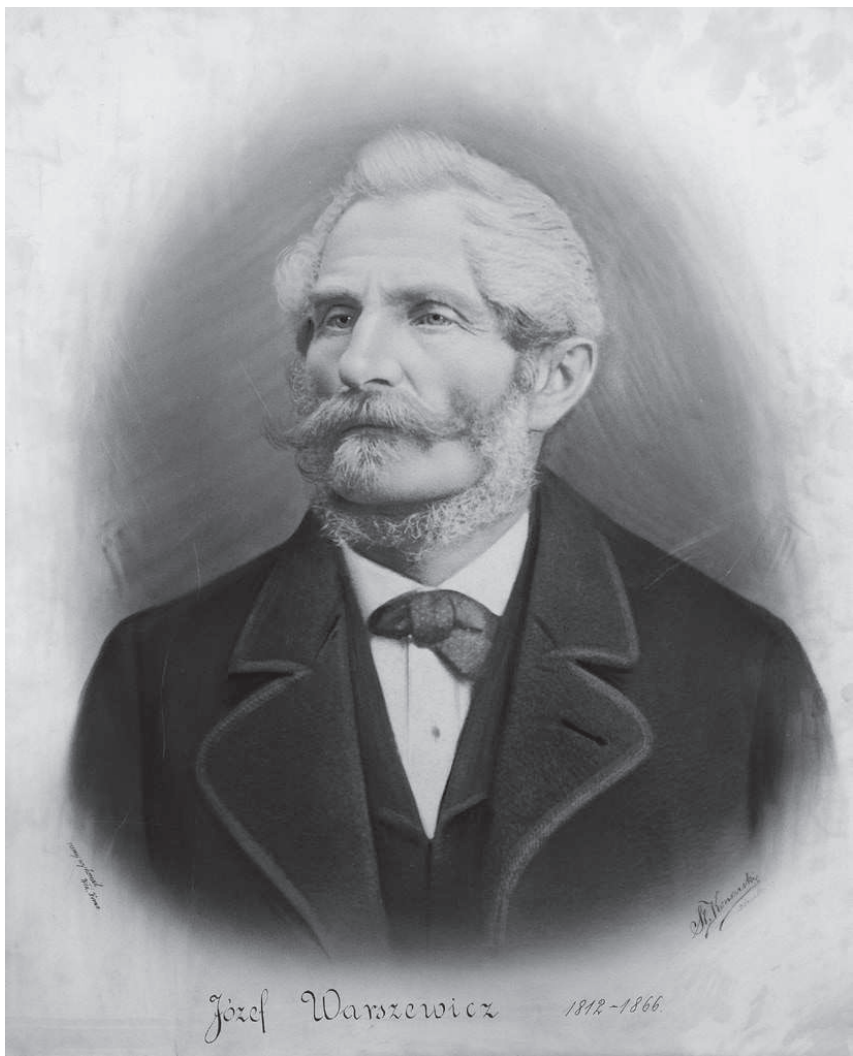

Figure 1. Józef Warszewicz (retouched photo, photographer unknown). From the collection of the Museum of the Botanical Garden of the Jagiellonian University. in Kraków in 1853 and ending with his death in 1866. Kraków, the former capital of Poland, city of the coronations and eternal rest of Polish kings, had been incorporated into the Austrian Empire in 1846 and in the middle of the nineteenth century was a small frontier town. Since 1783, the Botanical Garden of the Jagiellonian University had functioned there.

One must first identify the reason for Warszewicz's relocation to Kraków. The main one was the desire of the Botanical Garden's director to improve the condition of the Garden. The incumbent gardener, since 1835, was Wacław Koczara (Koczarski) (Czerwiakowski, 1864, pp. 162-163). In the late 1840s he led to significant losses in the Garden's plant collections (Czerwiakowski, 1864, pp. 189-190). Therefore the director of the Garden, Professor Ignacy Rafat Czerwiakowski (1808-1882), began to search for a possible successor to Koczara.

\footnotetext{
After writing this article, Prof. Romualdas Šviedrys kindly forwarded me some of his studies on Warszewicz (Šviedrys, 2008-2009; 2011; 2012), for which I am very grateful to him.
} 
His choice fell on Józef Warszewicz, his friend from their mutual studies in Berlin: Czerwiakowski had studied there in 1837 (AUJ, n.d., a), when Warszewicz was an assistant gardener at the Botanical Garden of Friedrich-Wilhelms-Universität. This is where they met (Czerwiakowski, 1864, p. 191). In 1850, Czerwiakowski, looking for a successor to Koczara, wrote Warszewicz with a proposal to accept work at the Kraków Botanical Garden. In response, Warszewicz wrote him on 15 October 1850: "In Prussia and England I was offered the post of Botanical Garden Inspector, but you know very well that a Pole always wants to be useful for the Motherland, and so it is my first duty to be useful for my homeland." (Piekiełko, 1983, p. 23). Warszewicz had even visited Kraków briefly toward the end of 1850 (Czerwiakowski, 1864, p. 192). Since there was no free post for him then, he had had to leave. As it turned out, Czerwiakowski had started efforts which were to last several years to employ Warszewicz in the University Garden. In his letter of 9 November 1850 to the rector of the Jagiellonian University, Czerwiakowski presented Warszewicz as the most suitable candidate for Koczara's position and asked for the appointment of Warszewicz as the Inspector of the Garden (AUJ, 1849-1925). News of the appointment was sent to the appointee in America; Warszewicz promised to come to Kraków as soon as possible (AUJ, 1852-1925). On 3 December 1850, the Council of the Faculty of Philosophy of the Jagiellonian University agreed with Czerwiakowski's proposal. On 28 June 1851, the incumbent gardener, Wackaw Koczara, requested retirement as of 1 May 1852. The Council of the Faculty of Philosophy approved his request and appointed Warszewicz in his place. Appropriate letters were sent to Vienna. For the next half year, the Ministry of Denominations and Education in Vienna was silent on the matter. Therefore, on 16 January 1852, Czerwiakowski renewed his request to the Faculty of Philosophy concerning Warszewicz. On 16 June 1852, the Ministry of Denominations and Education granted retirement for Koczara but decided nothing concerning Warszewicz. On 14 July 1852, Czerwiakowski again wrote to the Council of the Faculty of Philosophy asking the faculty to renew its request to the Ministry of Denominations and Education in Vienna for the appointment of Warszewicz or "anyone with knowledge of the Polish language, as the garden workers do not know any other language."

Here a brief explanation of the problem with the Polish language is needed. In 1795, Poland had lost its independence. The southern part of the nation was annexed by Austria. In 1815, the Congress of Vienna created a small country, the Republic of Kraków. This Republic existed until 1846 when it was incorporated into the Austrian monarchy and subjected to severe Germanisation. The official language in Kraków was then, during the efforts to employ Warszewicz, German, 
which the garden workers apparently did not know. Thus the requirement of knowledge of Polish was imposed for the future Inspector of the Garden.

On 19 July 1852, Czerwiakowski, not having obtained the appointment for Warszewicz, asked the University Senate for the temporary nomination of Feliks Berdau (1826-1895), his assistant and an outstanding florist, but lacking knowledge in horticulture (AUJ, 1852-1925) as gardener. Unexpectedly, the ministry very quickly confirmed the post for Berdau (AUJ, 1849-1925). Apparently concerned about the lack of news from Kraków, Warszewicz wrote a letter to Czerwiakowski on 23 August 1852. He asked about the progress of efforts

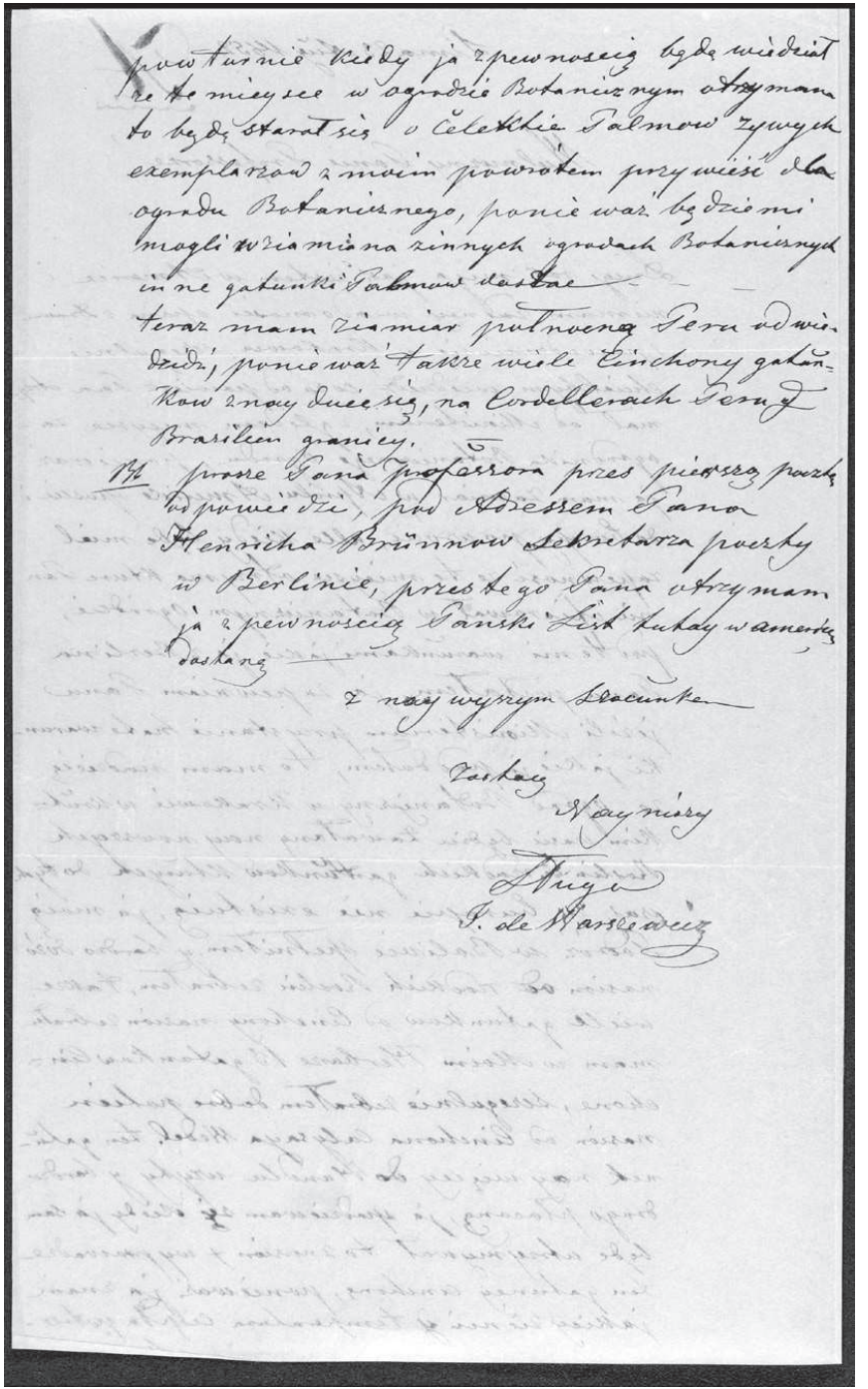

Figure 2. Letter of Józef Warszewicz to Ignacy Rafał Czerwiakowski, Lima, 23 August 1852. From the collection of the Jagiellonian University Archives. to appoint him Inspector of the Garden, and promised to collect rare plant species for the Botanical Garden (Fig. 2; AUJ, 1852-1925). In connection with the planning work for the coming spring in the Garden and the lack of a gardener, Czerwiakowski sent several letters to the Ministry asking for the appointment of Warszewicz or, failing that, anyone else. Finally, the answer came. The Ministry of Denominations and Education in Vienna stated that the reasons cited by the Department of Philosophy of the Jagiellonian University were not important, thus the Ministry did not agree to the appointment of Warszewicz. Despite the Ministry's negative attitude, Czerwiakowski did not lose hope. On 21 February 1853 he prepared a review of Warszewicz, from which we learn that Warszewicz had 
promised to come to Kraków immediately after receiving the appointment as Inspector of the Garden, and that acting gardener Feliks Berdau was unsuitable for this position due to his lack of proper horticultural background. The future inspector was supposed to know the Polish language, as Warszewicz did; Czerwiakowski, knowing him personally, could certify this. Warszewicz had excellent references from Alexander von Humboldt and Carl Sigismund Kunth (1788-1850), professor of botany at Berlin University. Finally, on 25 May 1853, the Faculty of Philosophy of the Jagiellonian University received a letter informing that the "Ministry of Denominations and Education in Vienna and [Galician] Provincial Commission do not object to the Prussian subject Warszewicz becoming Inspector of the Botanical Garden of the Jagiellonian University upon his return from America" (AUJ, 1852-1925).

Thus, after nearly four years, the battle for the appointment of Warszewicz as Inspector of the Botanical Garden in Kraków happily came to an end. What could have been the reason for the resistance of the Ministry? Perhaps the Ministry had plans for an Austrian of German nationality (or at least a nonPole) to be employed in the Garden. We do not know. Warszewicz, a subject of Prussia, had to become an Austrian subject after taking the job. Certainly, major roles were played by the existing policy of Germanisation of the Poles and the disfavour in which the Austrian government held Poles.

Warszewicz arrived in Kraków in November 1853, and on 1 March 1854 he was appointed Inspector of the Botanical Garden, a master gardener with considerable scientific and horticultural skills (Czerwiakowski, 1864, pp. 192193). It should be noted that the post of Inspector was specially created for him, and that since that time the position has survived to the present day. An official apartment in the western pavilion of the Botanical Garden had already been prepared for Warszewicz. 


\section{Warszewicz's work on the reorganisation of the Botanical Garden and new projects}

As has already been mentioned, the state of the Botanical Garden before Warszewicz's arrival was unsatisfactory. Warszewicz immediately took responsibility for what needed to be done. The Jagiellonian University Archives have a special file devoted to the improvements made at that time in the Botanical Garden (AUJ, n.d, $b$ ). On this basis of that it is possible to reconstruct the main work of Warszewicz.

In 1855, Warszewicz built a greenhouse in which he grew plants from received seeds. The same year he rebuilt the channels surrounding the Garden. In 1857, the pond, which was located in the center of the Botanical Garden (an oxbow of the Vistula river), was rebuilt, receiving its present shape, and in its center an island was built which still exists today. Aquatic vegetation in oak baskets was introduced at the edge of the pond. An old rock garden by the pond was removed and its building blocks used in the construction of the island. In 1859, Warszewicz was busy altering a greenhouse for his collections. In 1861, he arranged a section for coniferous plants. The following year, he built a small palm house (Czerwiakowski, 1864, pp. 206-210). Two years later, Warszewicz rebuilt the largest greenhouses. A newly-created section in the Garden was dedicated to acclimatisation of plants. Here Warszewicz bred species to be introduced into cultivation (Piekiełko, 1983, p. 53).

Among other construction activities of Warszewicz, a new greenhouse was built adjoining the old ones. In this way a compact, modern greenhouse complex was established, completed with a vast semicircular palm house (Czerwiakowski, 1864, pp. 203-204).

\section{The enlargement of the Botanical Garden's plant collections}

Warszewicz came to Kraków in November 1853, bringing with him a large collection of tropical plants that were the result of his travels to South and Central America. He systematically enriched this collection over the next years with trips to western European botanical centres. In 1855, Warszewicz received a four-week leave in order to collect plants and visit the botanical gardens in Berlin, Vienna and the Netherlands (AUJ, 1855). In subsequent years, usually in 
June, Warszewicz was given one-month vacations: in 1860, he visited Germany; in 1861, Belgium; and in 1862, London (AUJ, 1849-1925). He brought back both living plants and seeds from which he then obtained seedlings. Through his activities the Kraków Botanical Garden become one of the richest in Europe.

In 1864, Czerwiakowski and Warszewicz published a catalogue of the plants of the Kraków Botanical Garden, Catalogus plantarum (Fig. 3; Czerwiakowski \& Warszewicz, 1864), which contained the large number of 9,470 species and varieties of plants, including 3,779 (constituting 39\%) greenhouse plants. Among the latter, the orchid collection, consisting of 325 species, many of them newly discovered by Warszewicz and named in his honour (e.g., Oncidium warszewiczii Rchb.f), was the most valuable. Besides orchids, in the greenhouses there were also other collections of rare tropical plants. The Botanical Garden had a large collection of South American Araceae (84 species and varieties), Palmae (52 species and varieties), and Cactaceae (208 species and varieties). Outside the greenhouses, a huge collection of ornamental plants of the genus Canna (68 species and varieties) was cultivated, including many new species imported to Europe for the first time by Warszewicz (Czerwiakowski \& Warszewicz, 1864). 
Warszewicz also brought his herbarium to Kraków (Fig. 4). It was kept in the Cabinet of Natural History at the Jagiellonian University, where it remained after his death. It was not, however, included in the inventory because the plants had not been identified. During World War I, Stanisław Kulczyński (1895-1975) identified part of this collection (Köhler, 1999, p. 25).

\section{Zoological collections}

When Warszewicz came to Kraków in November 1853, he also brought with him a collection of tropical animals (Schmidt, [1857]1858, p. 237). During his first expedition

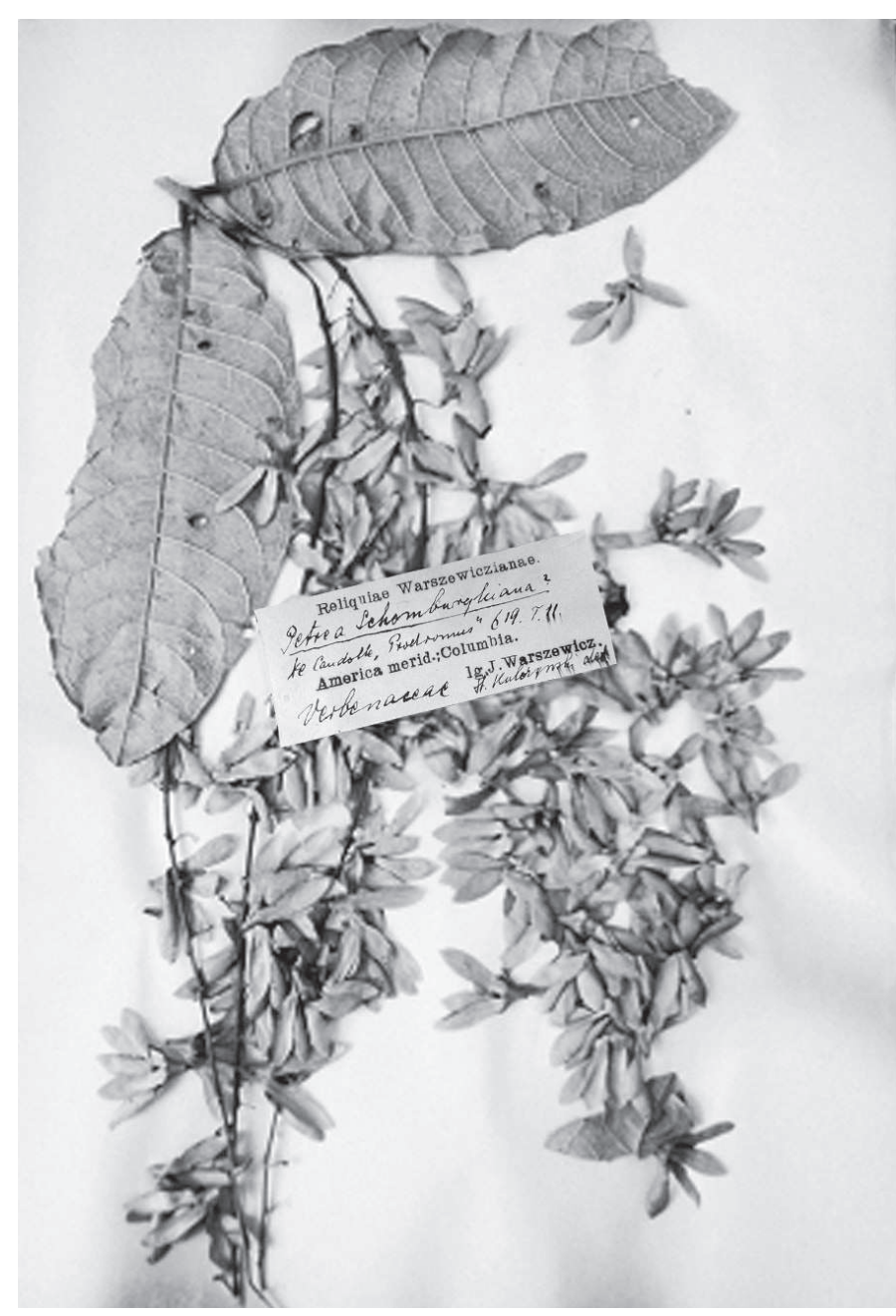

Figure 4. Specimen of Petrea schomburgkiana from the herbarium of J. Warszewicz. Herbarium of the Institute of Botany of the Jagiellonian University. Photo P. Köhler. to Central America, in addition to plants, Warszewicz also collected zoological specimens: insects, birds (e.g., hummingbirds), amphibians, mussels, and monkeys (F. Be., 1867, pp. 549-550). The hummingbirds were identified by John Gould (18041881), a famous English ornithologist (F. Be., 1867, p. 551). Warszewicz gave other zoological specimens (such as birds, insects, reptiles and shells) to various museums in Europe. In January 1856, the Zoological Museum of the Jagiellonian University purchased 49 specimens of animals (both invertebrates and vertebrates) from Warszewicz for 30 florins. The following year, also in January, the Museum purchased 48 specimens of South-American amphibians, reptiles and fish. In addition, the Museum received three specimens of hummingbirds from Warszewicz in 1864 (Beiersdorf, 2000, pp. 39, 40, 98). 
In 1857, Warszewicz's Kraków collection was catalogued by Oscar Schmidt (1823-1886), who headed the museum at that time (F. Be., 1867, p. 552; Schmidt, 1857; [1857]1858, p. 237). His publication includes descriptions of 17 new species and 1 genus new to science. The herpetological collection, consisting of 23 specimens, was catalogued again in 1970 by Savage (1970, p. 278). ${ }^{2}$

\section{The balance of his 13 years of life in Kraków}

During his life in Kraków, Warszewicz enjoyed great authority and esteem. As early as in 1861, the Warsaw journal Tygodnik Illustrowany ('Illustrated Weekly') published an extensive biography of Warszewicz along with his portrait (F.B., 1861). So far such an honour had only been bestowed upon outstanding scientists. On 11 November 1865, he was elected an active local member of the Academic Society of Kraków ${ }^{3}$ (Köhler, 2002, pp. 24-25); previously, he had been elected an honorary member of the Poznań Society of Friends of Science ('Zmarli członkowie...', 1878, p. 426). He was visited not only by other Polish botanists, such as Stanisław Batys Gorski

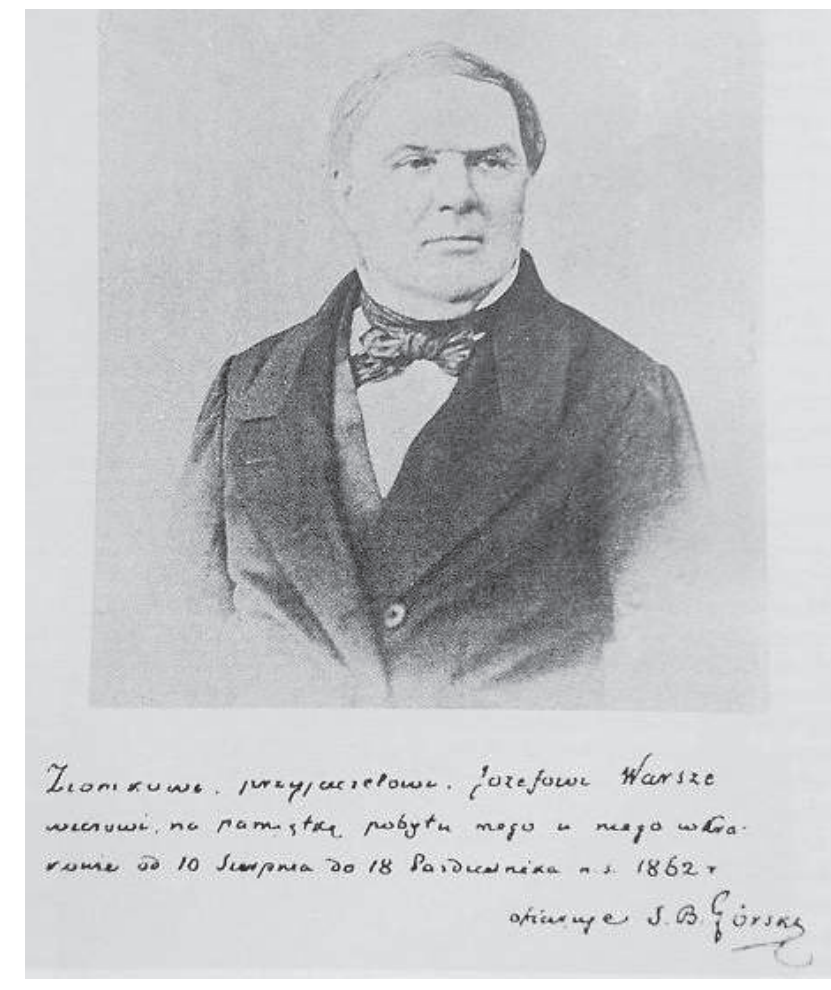

Figure 5. Photo of Stanisław Batys Gorski (1802-1864) with dedication to Józef Warszewicz: For my compatriot and friend Józef Warszewicz, to commemorate my stay with him in Kraków from 10 August to 18 October N[ew] S[tyle] 1862, S[tanisław] $\mathrm{B}$ [atys] Górski.

2 He mistakenly supposed that Warszewicz's collection was located in the Zoological Museum of the Jagiellonian University only as of 1870 . This cannot be true, since as early as in 1857 the collection was described as located in this museum.

3 It is worth noting that seven years later the society was transformed into the Academy of Sciences and Letters (since 1919, the Polish Academy of Sciences and Letters). 
(1802-1864) ${ }^{4}$ who visited him in 1862 and presented him with his photo, complete with a dedication (Fig. 5), but also by other eminent figures of Polish society, such as Stanisław Moniuszko (1819-1872), the most outstanding nineteenth-century Polish opera composer, who visited him in May 1858 (Moniuszko, 1969, p. 306). Warszewicz was respected by foreign naturalists and horticultural societies. While he lived in Kraków, he was several times appointed a judge of foreign horticultural exhibitions, in countries including Austria, Belgium and the Netherlands. Several times he received awards at exhibitions for the breeding of beautiful garden plant varieties (F. Be., 1867, p. 551).

One of Warszewicz's most outstanding achievements in horticulture was the introduction of ornamental plants of the genus Canna into widespread cultivation (Ziobrowski, 1927, pp. 31-32). The number of species and varieties cultivated in the Kraków Botanical Garden thanks to Warszewicz's efforts was impressive. This is reflected in the content of Index Seminum, which, in the years 1860-1863, consisted of nearly 5,000 species and varieties of plants (Fig. 6; Czerwiakowski, 1864, p. 223).

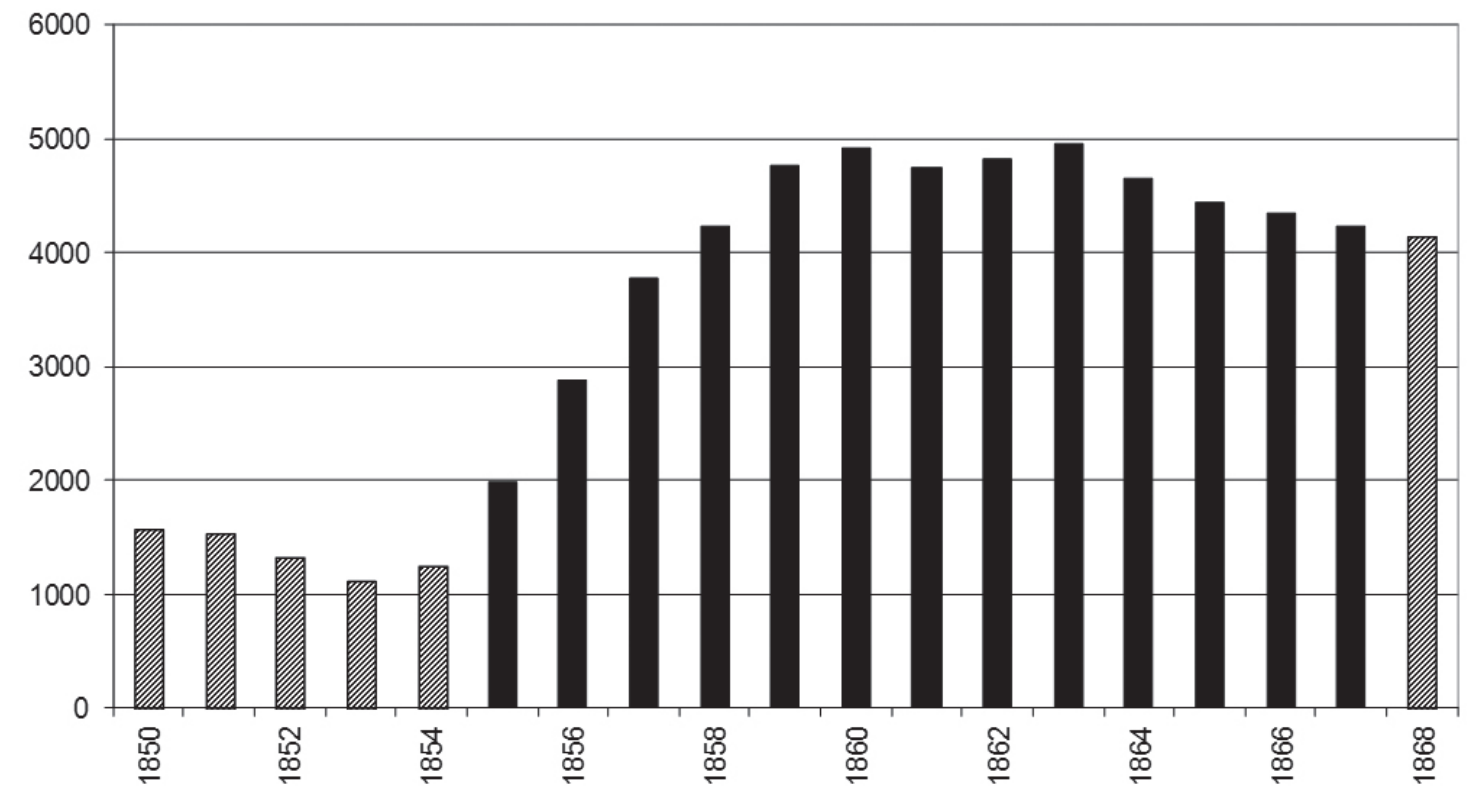

Figure 6. Number of species in Index seminum in 1850-1868. Black bars indicate the years of J. Warszewicz's work.

\footnotetext{
Stanisław Batys Gorski studied natural sciences and medicine at the University of Vilna. From 1829-1841, he headed the botanical garden of Vilna. From 1832-1841, he was an assistant professor at the Vilna Medical-Surgical Academy. After its closing he lived in the countryside (Z. P. [Z. Podbielkowski], 1987).
} 


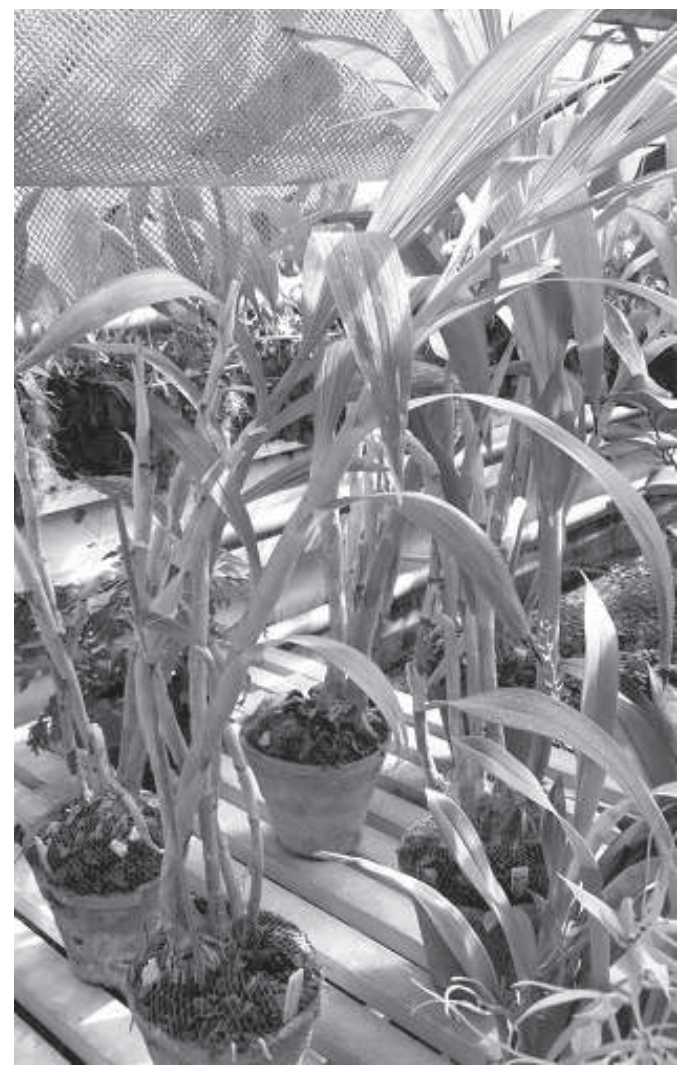

Figure 7. Orchid Cyrtopodium andersonii R.Br. - clone of specimen imported by J. Warszewicz. Collections of the Botanical Garden of Jagiellonian University. Photo P. Köhler.

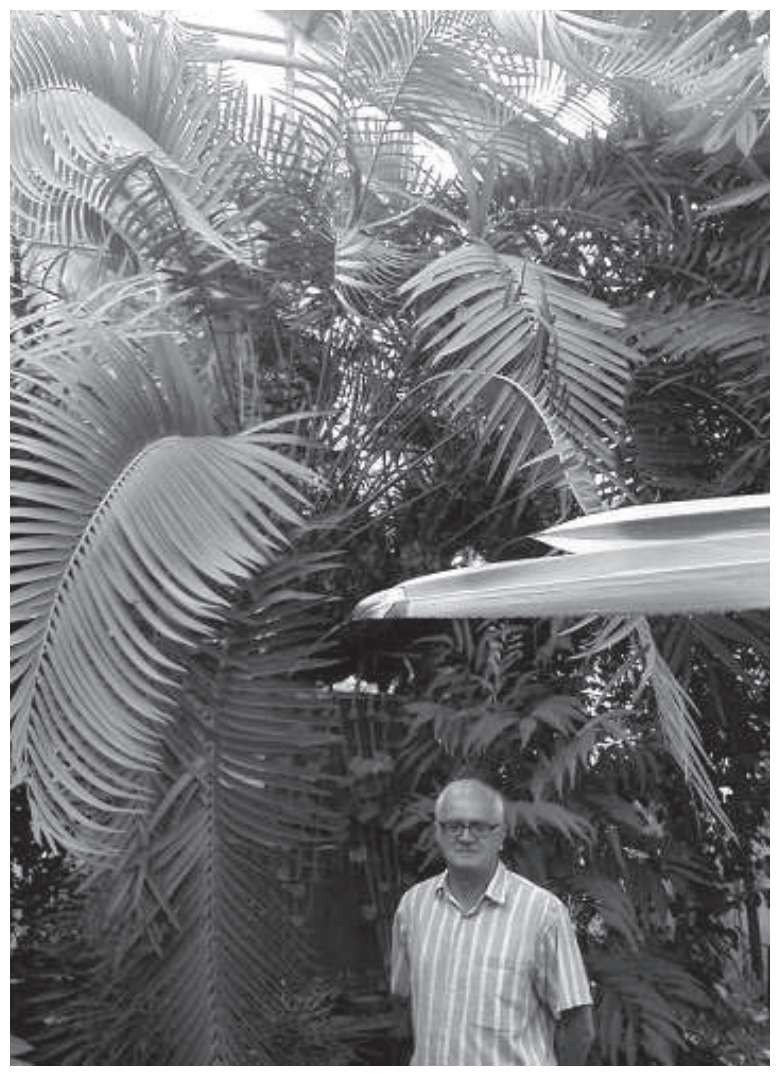

Figure 8. Cycad Ceratozamia robusta Miq. J. Warszewicz planted this specimen by hand. Collections of the Botanical Garden of Jagiellonian University.

Photo P. Köhler.

The measure of Warszewicz's vast knowledge and his special position as Inspector of the Botanical Garden was the co-authorship (along with the Director of the Garden) of the Index Seminum in the period 1855-1866. Another joint publication, already mentioned, was the Catalogus plantarum, published to commemorate the $500^{\text {th }}$ anniversary of the Jagiellonian University. Warszewicz's only self-publication during his Kraków period was a small booklet published in Amsterdam: Handelspflanzen, welche für ostindische Colonisten wichtig und von Grossem werthe sein können ('Commercial plants East Indian settlers may find important and worth knowing'; Warszewicz, 1865).

In 1863, during the January Uprising in Congress Poland, Ignacy Rafał Czerwiakowski (then Rector of the Jagiellonian University), along with Warszewicz, secretly aided the youth movement supporting the uprising. According to tradition, a group of students, who took part in the Miechów 
expedition to Congress Poland (under Russian rule) of Apollinary Kurowski (1818-1878), marched out of the Botanical Garden, where they had hidden weapons in the old greenhouse (Piekiełko, 1983, p. 24).

At the end of the nineteenth century, the remarkable collection of plants of the Kraków Botanical Garden declined in numbers. Most of the species introduced by Warszewicz became extinct (Piekiełko, 1983, p. 53). In 1907, a wooden greenhouse collapsed, destroying about 600 species of orchids, and in 1912 Warszewicz's wooden greenhouse, containing his collection of tropical Araceae, burned down (JUA, 1851-1935/1850-1937). The destruction was completed by World War II (including the freezing of the greenhouse by the Germans). According to tradition, from the rich collection of Warszewicz only two species have survived to the present day: the orchid Cyrtopodium andersonii R.Br. (Fig. 7) and the cycad Ceratozamia robusta Miq. (Fig. 8) (Piekiełko, 1983, p. 57).

\section{Commemoration of Warszewicz in Kraków}

Józef Warszewicz died in his flat (on the first floor of the western guardhouse in the Botanical Garden) on 29 December 1866. The following day, Czerwiakowski sent a letter to the Senate of the Jagiellonian University notifying them that "Józef Warszewicz died yesterday at 5:30 in the afternoon" (AUJ, 1849-1925). Warszewicz was buried in Rakowicki Cemetery in Kraków, which was (and still is) one of the most important cemeteries in Poland. Interestingly, the Warszewicz tomb was not built in the form of a traditional tombstone with which cemeteries are replete. Instead, a neo-Gothic column topped with a cross was erected (in 1868) at the grave (Fig. 9). On the column is a plaque with the following inscription (in Polish):

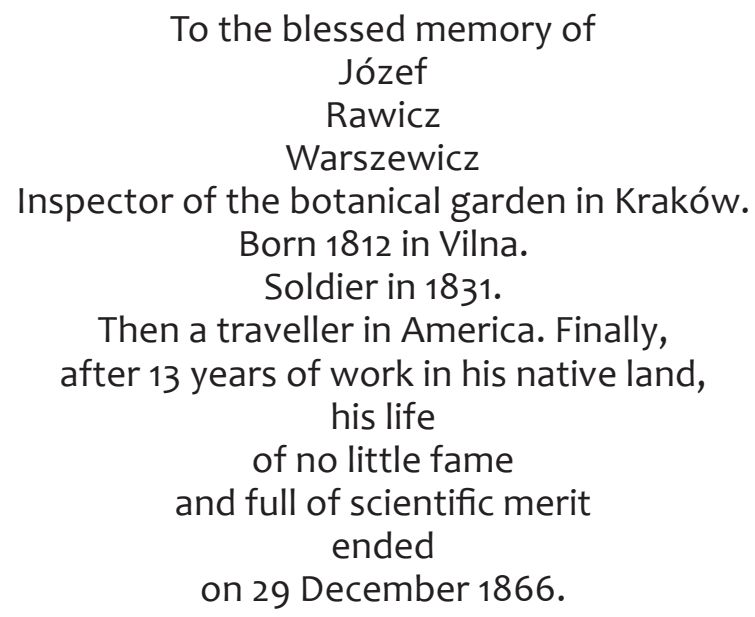


Index Seminum, published since 1806 , is a catalog of seeds that Kraków Botanical Garden offers to exchange with other botanical gardens. The issue of Index Seminum released in 1867 after the death of Warszewicz included a title page with a black mourning frame.

After Warszewicz's death, in recognition of his enormous services to Kraków Botanical Garden, his monument was erected there (Fig. 10, see p. 32). The monument consists of a four-sided column, topped by a bust of Warszewicz in ancient Roman style. The bust was sculpted in 1862 by Franciszek Wyspiański (1836-1901), a Kraków sculptor and father of one of the greatest Polish poets, painters and playwrights, Stanisław Wyspiański (1869-1907). On the

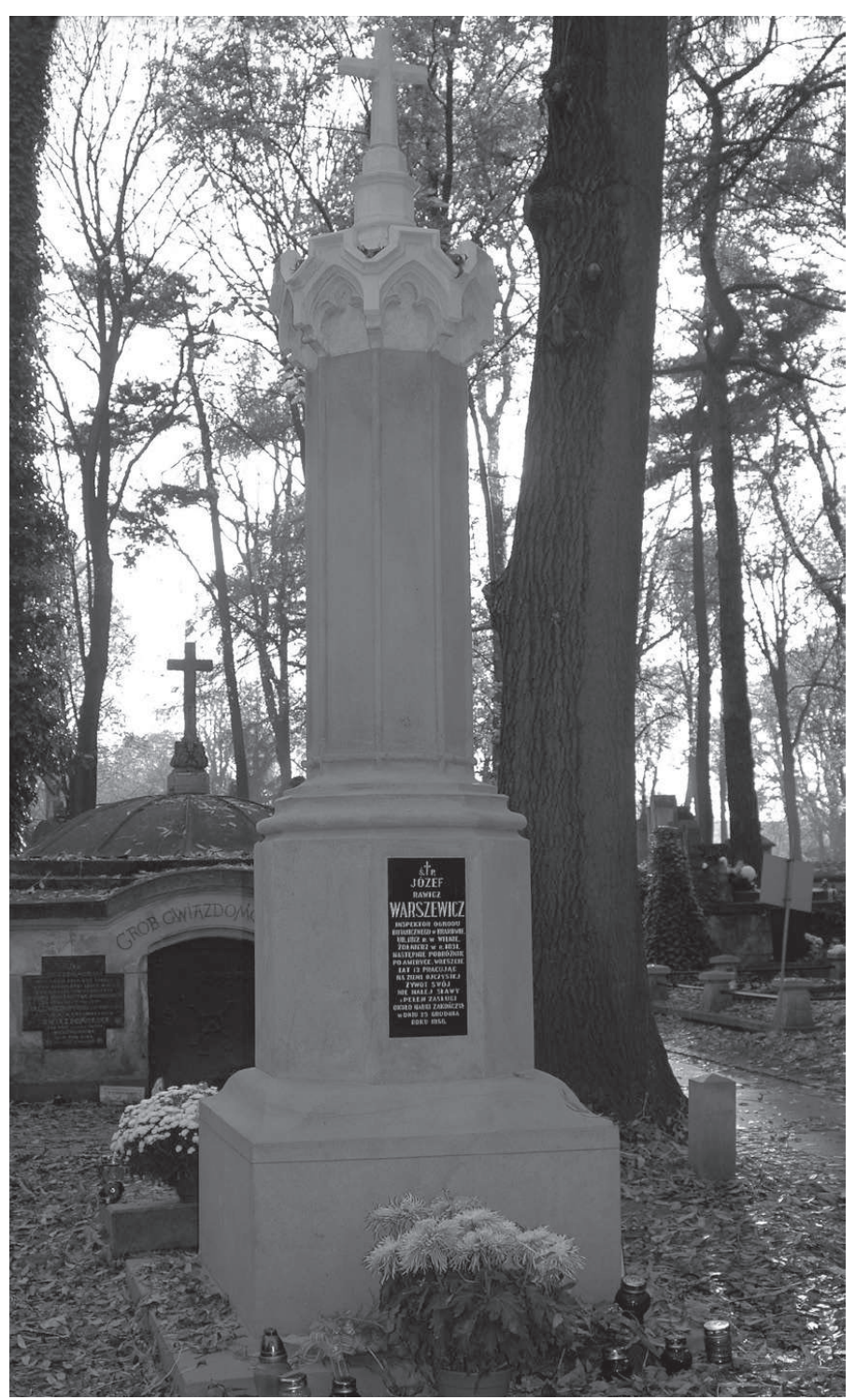

Figure 9. Grave of Józef Warszewicz at Rakowicki Cemetery in Kraków. Sculptor Walery Gadomski (1833-1911). Photo A. Mróz. monument's pedestal is a plaque with a poem by Wincenty Pol (1807-1872), poet and Warszewicz's comrade-in-arms from the time of the November Uprising (1831): 
O Litwo, święta Matko Warszewicza.

Jakże ci błogo w cieniu tych wawrzynów,

Którego blasku Ojczyźnie użycza

Poczciwa chwała Twych wybranych

Synów!

Uczniu Jundziłła! obiegłeś dwa światy,

Aby z zdobyczą wrócić do swych progów

I jak syn wierny czarownymi kwiaty

Osypać ołtarz Twych domowych Bogów.

Kwiat - to niewiele, ale kto da więcej -

I czy dla Ciebie to, Matko, nie jedno?

Byle Cię tylko kochać najgoręcej,

To Ty nie wzgardzisz i ofiarq biedną.

To nasza wiara, że nic nie przepada,

Co jak ofiara na ołtarz się składa.

Niech więc kwiatami pamięć syna słynie,

Który port stały znalazł w tej dziedzinie.
[O Lithuania, holy Mother of Warszewicz, How blissful for you is the shade of the laurels

Whose splendour is bestowed on the Fatherland

By the respectable glory of your select Sons!

Jundziłł's pupil! You have gone round two worlds

To return to your doorstep with a trophy And, as a faithful son, to bestrew the altar Of your household Gods with charming flowers.

A flower - it is not much, but who will give more

And is it not for you, Mother, all the same?

If someone loves you most ardently, You will not spurn even a poor offering. It is our belief that nothing is lost That is laid on the altar as a sacrifice. So let flowers commemorate the son Who found a permanent harbour in this domain. $]^{5}$

$5 \quad$ Translated by Dr. Jerzy Krzyszpień, for which I am very grateful to him. 


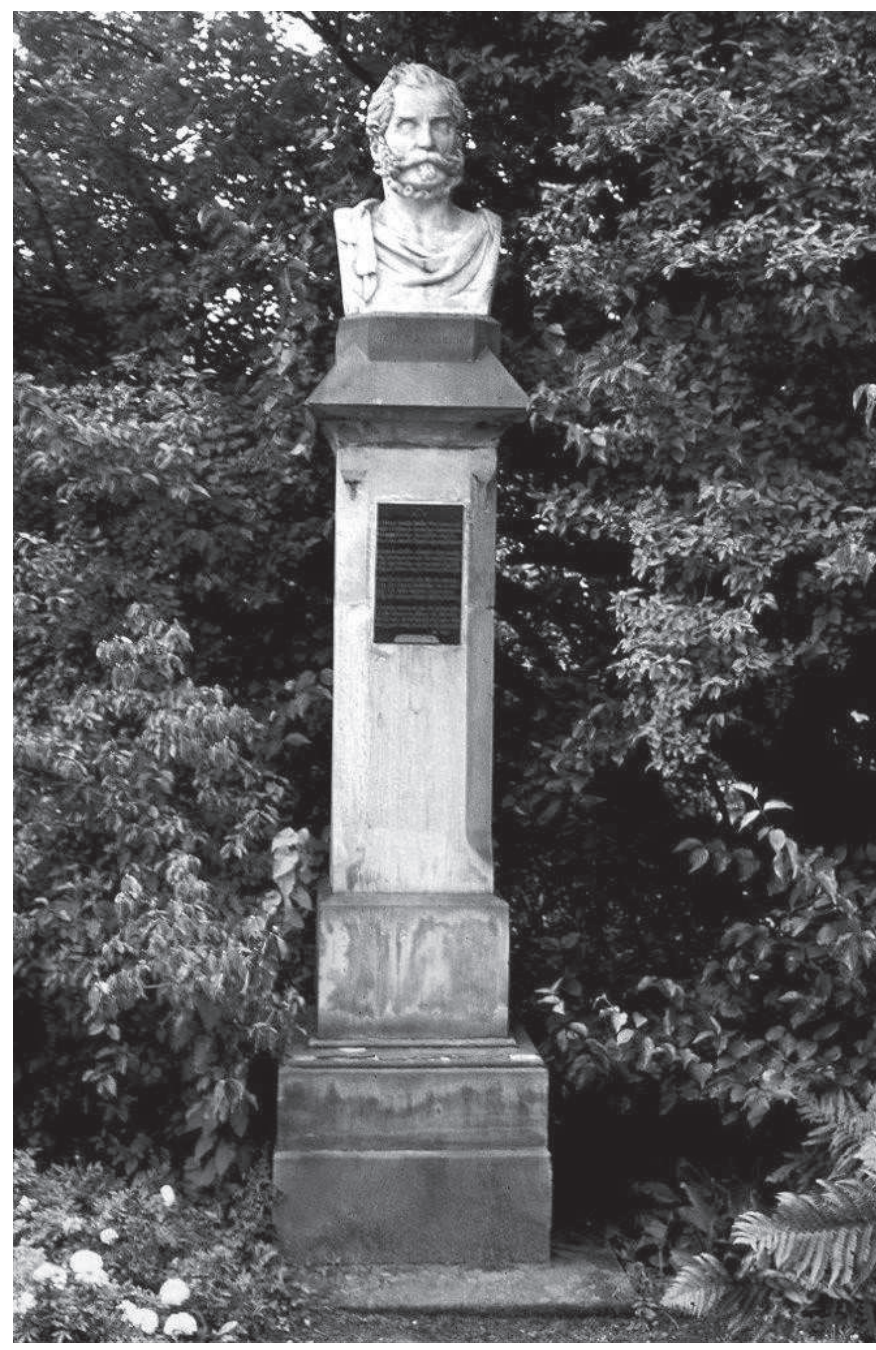

Figure 10. Warszewicz's monument in the

Botanical Garden of the Jagiellonian University. Photo A. Mróz.

Celebrations of the anniversaries of Warszewicz's birth and death have been organised in Kraków several times. The first such celebration took place on 8 September 1913, observing the centenary of his birth. The ceremony was organised by Professor Marian Raciborski (1863-1917), then Professor of Botany at the Jagiellonian University, director of the Botanical Garden and the Botanical Institute of the Jagiellonian University, and the Polish Association of Gardeners in Kraków. It was held both at the monument of Warszewicz and at his grave. In one of the preserved photos one can see, next to from the organisers, one of the last living students of Warszewicz, Ignacy Kluz ('Rocznica Warszewicza', 1913). The Polish Association of Gardeners in Kraków decided to adopt the name of Warszewicz as its own ('Z roku rocznic...', 1913).

The sixtieth anniversary of his death was observed on 2 January 1927. The celebration was organised by the Central Trade Union of Christian Gardeners and Garden Helpers. After the morning service in Warszewicz's name in the Church of St. Nicholas in Kraków, flowers were laid at Warszewicz's monument in the Botanical Garden of the Jagiellonian University. Then Professor Władysław Szafer (1886-1970), director of the Botanical Garden, outlined Warszewicz's biography, works and contributions to science and to Poland. After visiting the Garden and its greenhouses, participants proceeded to Rakowicki Cemetery and laid a wreath on the grave of Warszewicz (Gołębski, 1927). 

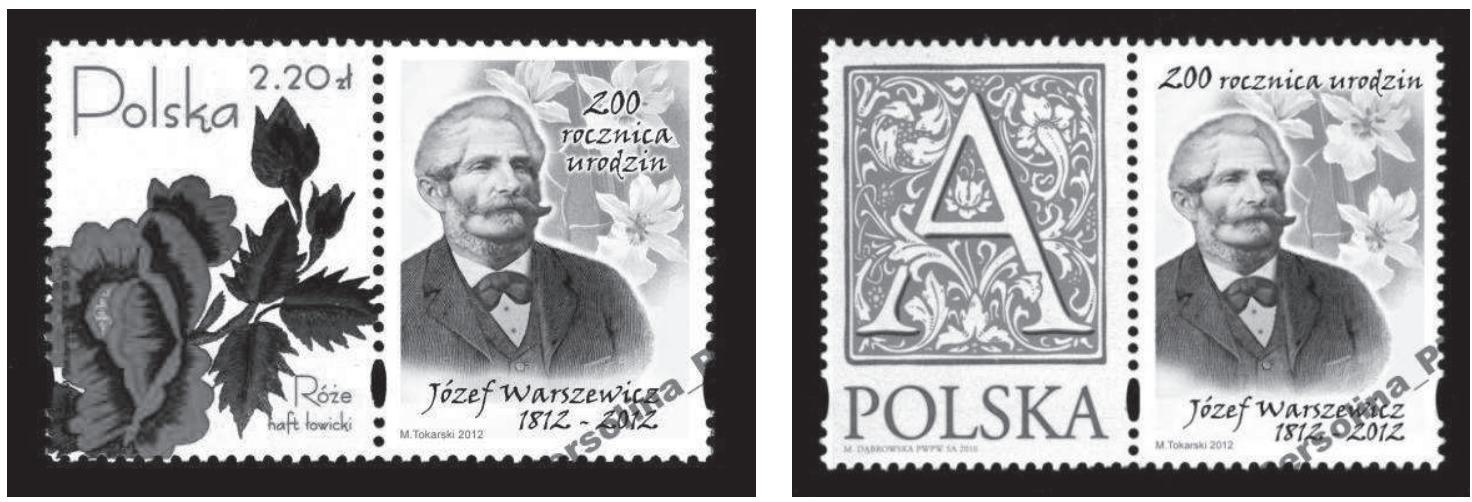

Figure 11. Two postage stamps issued by Polish Post on the occasion of the $200^{\text {th }}$ anniversary of Warszewicz's birth.

The $100^{\text {th }}$ anniversary of Warszewicz's death was observed on 23 November 1966. At the premises of the Polish Federation of Engineering (on Straszewski Street in Kraków), an evening dedicated to the memory of Warszewicz was organised, including a lecture delivered by Professor Władysław Szafer ('Pamięci wybitnego...', 1966; Wróbel-Stermińska, 1966).

One of the forms of commemoration of outstanding individuals is naming a street or a square after him or her. In Kraków, one of the streets located in the tenth district, Swoszowice, the spa district of Kraków, in the southern part of the town, is dedicated to Warszewicz. Warszewicz Street (in Polish: Ulica Warszewicza) is about 600 metres long. The name was given on 24 October 1977 by resolution of the National Council of the City of Kraków (Dziennik Urzędowy..., 1977). Thus, the memory of Józef Warszewicz is perpetuated in Kraków by his statue and by the street named after him.

Beyond Kraków, the memory of Warszewicz is also perpetually honoured at a national level. One of the streets in Nowy Sącz, a city in Kraków Voivodeship, in southern Poland, is named after Warszewicz (the name was given on 5 October 1979 by resolution of the National Council of the City of Nowy Sącz). On 22 June 1962, the former horticultural secondary school (now Complex of Schools) in Prószków, Opole Voivodeship, was named after Józef Warszewicz. On 3 June 1989, the Józef Warszewicz Polish Society of Orchids (Polskie Towarzystwo Storczykowe im. Józefa Warszewicza) was registered. Numbering about sixty members, the main objective of the society's activity was to disseminate information about the family Orchidaceae. The society planned to publish a journal, Warszewicziana (Jagiełło, 1989), but did not succeed. The $200^{\text {th }}$ anniversary of Warszewicz's birth was honoured by the Polish Post, with two stamps issued on 8 September 2012 (Fig. 11). 


\section{References}

AUJ (n.d., a), Personal folder of Ignacy Rafat Czerwiakowski, AUJ S II 619, Archives of the Jagiellonian University, Kraków.

— (n.d., b), Botanical Garden, Z 10, Archives of the Jagiellonian University, Kraków. (1849-1925), Botanical Garden. Management and personnel, 1849-1925, AUJ S II 877, Archives of the Jagiellonian University, Kraków.

— (1851-1935/1850-1937), Botanical Garden. Plants 1851-1935, buildings, land and equipment 1850-1937, AUJ S II 879, Archives of the Jagiellonian University, Kraków.

— (1852-1925), Botanical Garden. Inspector 1852-1925, AUJ WF II 172, Archives of the Jagiellonian University, Kraków.

— (1855), Warszewicz's letter of 9 June 1855 to professors of Faculty of Philosophy of the Jagiellonian University, AUJ WF II 172, Archives of the Jagiellonian University, Kraków.

Beiersdorf, K. (2000), Dzieje Muzeum Zoologicznego Uniwersytetu Jagiellońskiego, Kraków: Delta Design.

Czerwiakowski, I. R. (1864), 'Rys historyczno-statystyczny Ogrodu Botanicznego krakowskiego, od jego zawiązku aż do r. 1864,' in Zakłady uniwersyteckie w Krakowie, Kraków: Nakł. c. k. Towarzystwa Naukowego, Druk. "Czasu” W. Kirchmayera, pp. 144-233.

Czerwiakowski, I. R. \& Warszewicz, J. (1864), Catalogus plantarum, quae in C. $R$. Horto Botanico Cracoviensi anno 1864 - ab erecta C. R. Universitate Studiorum Jagellonica quingentesimo, a fundato vero horto octogesimo educantur; secundum systema Endlicherianum ab Ignatio Raphaële Czerwiakowski Med. Dre, Botanices Professore p. o. ac Directore ejusdem Horti et Josepho Warszewicz Inspectore editus, Cracoviae: Typis C. R. Universitatis Jagellonicae.

Dziennik Urzędowy... (1977), Dziennik Urzędowy Rady Narodowej m. Krakowa, no. 22, pos. 99, 31 December 1977.

F.B. [Feliks Berdau] (1861), 'Józef Warszewicz,' Tygodnik Illustrowany, vol. 3, no. 89, pp. 209-210.

F. Be. [Feliks Berdau] (1867), 'Warszewicz, (Józef),' in Encyklopedyja Powszechna, vol. 26, Warszawa: Nakład, druk i własność S. Orgelbranda, pp. 548-552.

Gołębski, W. (1927), 'Obchód ku czci śp. Józefa Warszewicza,' Przegląd Ogrodniczy, vol. 10 , no. 2 , pp. 56-57.

Jagiełło, M. (1989), 'Polskie Towarzystwo Storczykowe im. J. Warszewicza. Joseph Warszewicz Orchid Society of Poland,' Wiadomości Botaniczne, vol. 34, no. 2, p. 37.

Köhler, P. (1999), 'Historia Zielnika Instytutu Botaniki Uniwersytetu Jagiellońskiego (KRA) w latach 1780-1910,' Kwartalnik Historii Nauki i Techniki, vol. 44, no. 2, pp. 7-60. 
(2002), Botanika w Towarzystwie Naukowym Krakowskim, Akademii Umiejętności i Polskiej Akademii Umiejętności. Botany at the Academic Society of Cracow, Academy of Sciences and Letters and the Polish Academy of Sciences and Letters (1815-1952), Seria: Studia i materiały do dziejów Polskiej Akademii Umiejętności, Kraków: Polska Akademia Umiejętności, vol. 2.

Köhler, P. \& Mirek, Z. (2010 [2011]), 'Nineteenth-century Polish researchers of the South American flora,' in Z. Mirek, A. Flakus, A. Krzanowski, A. Paulo \& J. Wojtusiak (eds.) The nature and culture of Latin America. Review of Polish Studies. Naturaleza y cultura de América Latina. Reseña de los estudios Polacos, Kraków: W. Szafer Institute of Botany, Polish Academy of Sciences, pp. 173-179.

Moniuszko, S. (1969), Listy zebrane. Collected letters, Kraków: Polskie Wydawnictwo Muzyczne.

'Pamięci wybitnego...' (1966), 'Pamięci wybitnego botanika,' Echo Krakowa, no. 21(274) (22 November 1966), p. 5.

Piekiełko, A. (1983), Historia Ogrodu Botanicznego Uniwersytetu Jagiellońskiego $w$ Krakowie, Varia - Uniwersytet Jagielloński, Kraków: nakł. Uniwersytetu Jagiellońskiego, Warszawa: Państwowe Wydawnictwo Naukowe, vol. 164.

'Rocznica Warszewicza' (1913), 'Rocznica Warszewicza,' Wszechświat, vol. 32, no. 36, pp. $575-576$.

Savage, J. M. (1970), 'On the trail of the golden frog: with Warszewicz and Gabb in Central America,' Proceedings of the California Academy of Sciences, Fourth Series, Festschrift for George Sprague Myers, vol. 38, no. 14, pp. 273-288.

Schmidt, O. (1857), 'Diagnosen neuer Frosche des zoologischen Cabinets zu Krakau,' Sitzungsberichte der Kaiserlichen Akademie der Wissenschaften in Wien, MathematischNaturwissenschaftliche Klasse, vol. 24, no. 1, pp. 10-15.

_ ([1857]1858), 'Deliciae herpetologicae Musei Zoologici Cracoviensis. Beschreibung der im k. k. Museum zu Krakau befindlichen, von J. v. Warszewicz in Neu-Granada und Bolivia gesammelten ungeschwänzten Batrachier,' Denkschriften der Kaiserlichen Akademie der Wissenschaften. Mathematisch-Naturwissenschaftliche Classe, vol. 14, zweite Abtheilung, pp. 237-258 + 3 tabl.

Šviedrys, R. (2008-2009), 'Orchidèjų medžiotojas iš Lietuvos,' [Parts 1-7] Mokslo Lietuva, 2008, no. 8 (386), pp. 1-2; no. 9 (387), pp. 1-2; no. 10 (388), pp. 1-2; no. 12 (390), pp. $1-2$; no. 13 (391), pp. $1-2$; no. 1 (401), pp. $1-2$; 2009, no. 2 (402), pp. 1-2.

(2011), 'Juozapas Varševičius - egzotinių orchidejuc atradèjas pietu Amerikoje,' in Historia et Sapientia. Mokslo istoriku ir filosofu, nuolatiniu kasmetines konferencijos Scientia et historia dalyviu, straipsniu rinkinys, Vilnius: Naujoji Romuva, pp. 57-86. (2012), 'Juozapas Varševičius - orchidèju atradejas,' Orchidejos, vol. 2, no. 8, pp. 29-31; vol. 3, no. 9, pp. 28-31. 
Warszewicz, J. v. (1865), 'Handelspflanzen, welche für ostindische Colonisten wichtig und von grossem Werthe sein können,' Bulletin du Congrès International de Botanique et d'Horticulture, convoqué à Amsterdam, au mois d'Avril 1865, Amsterdam, pp. 1-6.

Wróbel-Stermińska, W. (1966), 'W setną rocznicę śmierci Józefa Warszewicza,' Hasło Ogrodniczo-Rolnicze, vol. 23, pp. 335-336.

Z. P. [Z. Podbielkowski] (1987), 'Gorski Stanisław Batys (1802-1864),' in S. Feliksiak (ed.) Stownik biologów polskich, Warszawa: PWN, p. 190.

Ziobrowski, S. (1927), 'Rośliny nazwiskiem J. Warszewicza oznaczone,' Ogrodnictwo, vol. 23, pp. 14-25.

'Zmarli członkowie...' (1878), 'Zmarli członkowie Towarzystwa od zawiązania tegoż w roku 1857 do czerwca 1878 roku,' Roczniki Towarzystwa Przyjaciót Nauk Poznańskiego, vol. 10, pp. 425-429.

'Z roku rocznic...' (1913), 'Z roku rocznic. (Józef Warszewicz 1812-1866),' Tygodnik Illustrowany, vol. 54, no. 38 (27 September 1913), p. 767.

Piotr Köhler earned his MSc, PhD and habilitation in biology, with specialisation in history of botany, from the Jagiellonian University in Kraków, Poland. Now he is associate professor at the same university and head of the Z. Czeppe Department of Polar Research and Documentation (Institute of Botany, Jagiellonian University). His main research interests are history of botany, especially biographies of botanists, history of botanical institutions and botanical collections, history of polaristics: mainly Polish research activity in the Arctic and Antarctic, as well as historical ethnobotany. More recently he has been interested in Lysenkoism. In 2013, he edited the book Studia nad łysenkizmem w polskiej biologii. Studies in Lysenkoism in Polish Biology. 